http://e-journal.stit-islamic-village.ac.id/index.php/JM2PI

\title{
Analisis Pendidikan Karakter Anak Usia Dini Melalui Model Pembelajaran Sentra (Beyond Center and Circle Time)
}

\author{
Nurlia Alfianti \\ Program Studi Pendidikan Islam Anak Usia Dini, STIT Islamic Village Tangerang \\ Email: nurliaalfiantii@gmail.com
}

\begin{abstract}
The purpose of this research is to analyze early-children education through the beyond and circle time (BCCT) model.

The research is library research, conducted by collecting and analyzing data in the form of books; journals; earlier thesis; website; articles and UndangUndang Republik Indonesia relating to the beyond and circle time (BCCT) model. While the analysis of those data carried out using content analysis method.

The results showed that character education could be done appropriately through the beyond and circle time (BCCT) model. That is because of the process of its model, which is prioritizing character education.
\end{abstract}

Keywords: Education Character, Early Children Education, Beyond Circle and Time (BCCT) Model

\section{ABSTRAK}

Penelitian ini bertujuan untuk menganalisis pendidikan karakter anak usia dini melalui model pembelajaran sentra (Beyond Center and Circle Time).

Penelitian ini berbentuk kajian pustaka, dilakukan dengan mengumpulkan dan menelaab data berupa buku; jurnal; situs web; artikel dan Undang-Undang Republike Indonesia yang berkaitan dengan model pembelajaran sentra pada pendidikan karakter anak usia dini. Sedangkan analisis terhadap data-data tersebut dilakukan dengan metode analisis isi (content analisys).

Hasil penelitian menunjuk.kan, pendidikan karakter bisa dilakukan dengan tepat melalui model pembelajaran sentra (BCCT). Hal tersebut tampak dari proses pembelajaran sentra yang mengedepankan nilai-nilai karakter.

Kata Kunci: Pendidikan Karakter, Anak Usia Dini, Model Pembelajaran Sentra 


\section{PENDAHULUAN}

Era globalisasi saat ini memberikan dampak positif sekaligus dampak negatif bagi tumbuh kembang seorang anak. Adanya kemerosotan akhlak generasi milenial, zaman yang semakin marak akan kecanggihan teknologi, tayangan televisi yang minim sekali menampilkan tayangan edukasi untuk anak. Menghimpun data dari Komisi Penyiaran Indonesia, Seto Mulyadi menyatakan sekitar $39 \%$ konten tayangan televisi di Indonesia berupa iklan, $31 \%$ sinetron, $15 \%$ program berita dan hanya sekitar $0.07 \%$ yang tergolong mendidik anak-anak. M. Masri Muadz juga menyatakan,

“63\% remaja Indonesia pernah melakukan seks bebas. Sedangkan remaja korban narkoba di Indonesia ada 1,1 juta orang atau 3.9\% dari total jumlah korban."

Pendidikan karakter seharusnya menjadi pembahasan penting yang perlu ditindaklanjuti dan bukan hanya sekedar wacana, namun juga harus diaplikasikan secara nyata dan konsisten oleh setiap lembaga pendidikan, khususnya lembaga (PAUD). Tanpa adanya pendidikan karakter, maka akan semakin bobrok para generasi selanjutnya.

Pendidikan karakter di lembaga PAUD dapat diaplikasikan secara holistik melalui model pembelajaran sentra. Dengan pembelajaran sentra anak diberi kebebasan untuk bereksplorasi melalui main terarah, pembelajaran akan menjadi menyenangkan, aman dan bahagia untuk mereka, tanpa adanya tekanan, paksaan ataupun tuntutan. Karena jika anak belajar dalam kondisi tertekan, marah, sedih itu berarti otak anak dalam kondisi negatif, sehingga sulit untuk menerima pembelajaran. Proses pembelajaran sentra senantiasa menghadirkan suasana positif, serta sangat menghargai muru'ah, (perilaku atau karakter).

Oleh karena itu, pentingnya pendidikan karakter jika diberikan sejak usia dini melalui model pembelajaran yang sesuai dengan usia perkembangan anak. Melalui pembelajaran tersebut, nilai-nilai karakter yang terkandung dalam Perpres No. 87 Tahun 2017 dapat diterapkan. Lima nilai utama karakter yang 
terdapat didalam Perpres No.87 Tahun 2017 diantaranya adalah, religius, nasionalis, mandiri, gotong royong dan integritas. Nilai-nilai karakter tersebut merupakan nilai karakter yang dapat membentuk pribadi anak secara utuh, kelima nilai karakter tersebut tentu saling berkesinambungan dan tidak berdiri sendiri. Untuk itu, penulis menspesifikan dan memfokuskan penelitian ini pada lima nilai karakter tersebut dalam pembelajaran sentra.

\section{METODE}

Penelitian ini menggunakan studi kepustakaan atau disebut dengan Library Research. Penelitian kepustaakaan merupakan penelitian yang dilakukan oleh peneliti dengan cara mengumpulkan buku-buku, artikel, yang berkaitan dengan masalah dan tujuan penelitian. Buku tersebut dianggap sebagai sumber data yang akan diolah dan dianalisis seperti yang banyak dilakukan oleh ahli sejarah, sastra, dan bahasa (Danial A.R, 2009-80). Sedangkan analisis data menggunakan content analisys atau analisa isi. Lalu menggunakan teknik uji keabsahan data dengan mengutamakan kredibilitas data, display data, transferbilitas data, dan penarikan kesimpulan.

\section{PEMBAHASAN}

Pendidikan karakter dalam UU Nomor 20 Tahun 2003 Tentang Sistem Pendidikan Nasional Pasal 1 Ayat 1 disebutkan:

"Pendidikan adalah usaha sadar dan terencana untuk mewujudkan suasana belajar dan proses pembelajaran agar peserta didik secara aktif dapat mengembangkan potensi dirinya untuk memiliki kekuatan spiritual keagamaan, pengendalian diri, kepribadian, kecerdasan, akhlak mulia, serta keterampilan yang diperlukan bagi dirinya, masyarakat, bangsa dan negara" (Wiyani, 2017)

Herman H. Horn menyatakan, " Pendidikan merupakan proses yang terus menerus (abadi) dari penyesuaian yang lebih tinggi bagi makhluk manusia yang telah berkembang secara fisik dan mental" (Marbun, 2018) 
Sedangkan, karakter secara etimologis, berasal dari bahasa Yunani, yaitu charassein yang berarti "to engrave". Diartikan sebagai mengukir, melukis, memaatkan, atau menggoreskan. (Rianawati, 2014)

Disimpulkan bahwa, pendidikan karakter adalah usaha sadar dan terencana untuk mengembangkan akhlak mulia peserta didik dan memiliki nilai-nilai karakter positif.

Berkowitz dan Bier mengemukakan, pendidikan karakter ialah terwujudnya lingkungan sekolah yang mengembangkan etika, tanggung jawab siswa melalui model, dan pengajaran karakter yang baik lewat nilai-nilai yang universal (Maunah, 2015)

Pendidikan karakter dikemukakan oleh Samani dan Hariyanto, yaitu proses pemberian bimbingan kepada peserta didik untuk menjadi manusia utuh yang berkarakter dalam dimensi hati, rasa, karsa serta rasa, juga dikatakan bahwa karakter dijadikan nilai dasar yang membangun pribadi seseorang (Muchlas Samani \& Hariyanto, 2011)

Pendidikan karakter sangat tepat jika dimulai sejak anak berusia dini, usia dini adalah usia keemasan (golden age). Pada masa itu, pribadi manusia masih mudah dibentuk melalui pembiasaan-pembiasaan yang baik setiap hari dan sangat pesat perkembangannya.

Peraturan Presiden No.87 Tahun 2017 menjelaskan tentang penguatan pendidikan karakter, ada lima nilai utama karakter anak yang penting untuk dikembangkan. Karakter tersebut adalah religius, nasionalis, mandiri, gotong royong dan integritas. Lembar Peraturan Presiden No. 87 Tahun 2017 tersebut menyatakan:

"Penguatan Pendidikan Karakter (PPK) merupakan proses pembentukan, transformasi, dan mengembangkan potensi peserta didik agar berpikiran baik, berhati baik, dan berperilaku baik sesuai dengan falsafah hidup pancasila." (Anshori, 2017) 
"Penguatan Pendidikan Karakter yang selanjutnya merupakan gerakan pendidikan di bawah tanggung jawab satuan pendidikan untuk memperkuat karakter peserta didik melalui harmonisasi hati, olah rasa, olah pikir, dan olah raga dengan pelibatan dan kerjasama antara satuan pendidikan, keluarga, dan masyarakat sebagai bagian dari Gerakan Nasional Revolusi Mental (GNRM)." (Supraha, 2018)

Adapun lima nilai utama karakter dalam Perpres No. 87 Tahun 2017 sebagai berikut:

\section{Religius}

Karakter Religius adalah sikap yang mencerminkan beriman kepada Tuhan Yang Maha Esa, berakhlak mulia dan memiliki sikap toleransi. Dalam karakter ini, ada tiga dimensi relasi yang dibangun, pertama, hubungan manusia dengan Tuhan, dengan manusia lainnya, dan dengan lingkungan.

2. Nasionalis

Nasionalis berarti cinta tanah air, berprestasi, menaati hukum dan aturan negara yang berlaku, menghargai keberadaan suku, ras, adat dan budaya yang berbeda-beda.

3. Mandiri

Mandiri adalah karakter yang tidak suka bergantung pada oranglain, kreatif, melakukan sesuatu sendiri, dan juga professional.

4. Gotong Royong

Perilaku yang mencerminkan suka bekerjasama, bahu membahu melakukan sesuatu, suka menolong orang yang kesulitan dan membutuhkan.

5. Integritas

Integritas adalah karakter yang dapat dipercaya oleh oranglain. Konsisten terhadap tindakan dan perilaku ditunjukkan dengan aktif terlibat dalam kehidupan sosial yang berdasarkan kebenaran (Anshori, 2017) 
Karakter-karakter tersebut tentu saja dibentuk melalui pembiasaan, dilatih secara konsisten menjadi karakter dan budaya. Pendidikan karakter dapat efektif dilaksanakan melalui model pembelajaran sentra, karena pembelajaran sentra mengacu pada prinsip pembelajaran PAUD yaitu bermakna, menyenangkan, holistik dan terpadu, berbasis keilmuan, berorientasi pada keilmuan, serta berorientasi pada masyarakat (Fitriana, 2018).

Menurut Palupi dalam Farida Samad dan Bujuna Alhadad menjelaskan:

"Beyond Center and Circle Time digunakan untuk membantu anak-anak usia dini dalam memahami dasar-dasar membaca, menulis, dan menghitung. Dalam pendekatan ini pemahaman guru terhadap setiap pijakan akan membawa kegiatan pembelajaran di PAUD menjadi lebih kontekstual. Guru akan menghadirkan dunia nyata ke dalam kelas serta mampu memotivasi para siswa dalam mengaitkan pengetahuan yang dimiliki dengan penerapannya dalam kehidupan sehari-hari." (Mhd. Habibu Rahman, dkk, 2019)

Pembelajaran sentra pertama kali dikembangkan oleh Pamela Phelps di Florida, Amerika Serikat pada tahun 1970. Kemudian diadopsi oleh Wismiarti Tamin, pendiri Sekolah Al-Falah yang bertempat di Jalan Kelapa Dua Wetan No,4 Ciracas, Jakarta Timur, pada tahun 1996. Lalu disebarluaskan oleh pendiri Sekolah Al-Falah lewat pelatihan, seminar, penerbitan majalah setelah diadakannya training di sekolah tersebut (Yudhistira \& Siska Y. Massardi, 2012)

Pamela Phelps menyatakan bahwa konsep yang digunakan dalam pembelajaran sentra adalah constructivism, artinya, pembelajaran bukan hanya berpusat pada guru dan hafalan materi pelajaran, namun juga peserta didik membangun pengetahuan pada diri mereka (Ar-Raisul Karama Arifin \& Nur Ainy Fardana, 2014).

Jean Piaget mengemukakan, anak membangun pengetahuannya sendiri melalui hubungan yang berkelanjutan dengan lingkungan dan disesuaikan dengan tahap perkembangan anak. Lev Vygotsky juga mengemukakan bahwa pengetahuan tidak didapat dengan cara dialihkan dari oranglain, melainkan dari 
sesuatu yang dibangun serta diciptakan oleh anak. Menurut keduanya, anak merupakan pelaku aktif dalam suatu proses pembelajaran (Fitriana, 2018)

Adapun landasan teori lain mengenai pembelajaran sentra ialah sebagai berikut:

1. Teori perkembangan (Theory of development)

Dalam teori ini dinyatakan bahwa manusia dari lahir hingga dewasa memiliki pola perkembangan karakteristik tersendiri.

2. Teori belajar (Learning Theory)

Mengacu pada prinsip pendidikan anak usia dini, bahwa pembelajaran sentra dilakukan dengan cara bermain terarah, belajar melalui bermain dan bermain sambil belajar

3. Teori pembelajaran (Theory of Instruction)

Sama halnya dengan teori belajar, tujuan utama dari pembelajaran sentra ini ialah anak berkembang sesuai dengan usianya secara alamiah dan sesuai dengan perkembangan anak (Hanafi, 2019)

Dari beberapa teori diatas disimpulkan, model pembelajaran sentra merupakan model pembelajaran yang berpusat pada anak, setiap anak memiliki kesempatan yang sama untuk melakukan kegiatan, sehingga anak dapat menemukan minat dan bakatnya sendiri dan mengembangkan potensi dirinya.

Pamela Phelps mengembangkan tujuh sentra, diantaranya; sentra persiapan, sentra balok, sentra main peran besar, sentra main peran kecil, sentra bahan alam, sentra seni dan sentra musik. Lalu dikembangkan di Indonesia menjadi enam sentra: sentra persiapan, sentra balok, sentra bahan alam, sentra seni, sentra main peran dan sentra IMTAQ yang dikemukakan oleh Kusumandri dan Istyarini (Veny Iswantiningtyas \& Widi Wulansari, 2019). 
Adapun penjelasan dari sentra yang disebutkan diatas sebagai berikut (Ismail, 2013)

1. Sentra Persiapan

Sentra yang menyediakan fasilitas untuk kegiatan keaksaraan. Penekanan dalam sentra ini adalah anak dapat membaca, menulis, dan berhitung. Tujuannya supaya anak mampu berpikir teratur, gemar membaca, suka menulis dan berhitung.

2. Sentra Balok

Sentra balok menyediakan balok-balok sesuai dengan keinginan anak. Penekanan pada sentra ini adalah mengembangkan imajinasi dan kreasi anak dalam menyusun balok-balok membentuk seperti bangunan asli. Sentra balok memiliki tujuan agar anak dapat mengenal tipologi, ruang, dan bentuk. Pada sentra balok terdapat tahap-tahap kemampuan bermain balok yang dikemukakan oleh Harriet Johnson, Johnson melakukan penelitian dengan mengamati anak-anak bermain balok selama beberapa tahun yang akhirnya muncul tahap perkembangan balok ialah, membawa, menumpuk atau menjejer, membuat jembatan, membuat ruang, pola-poa dan simetri, representasi awal, representasi lanjut (Yudhistira \& Siska Y. Massardi, 2012: 142)

3. Sentra Bahan Alam

Sentra tempat anak untuk menstimulasi kecerdasan melalui penelitian bahan-bahan alam atau yang berada di sekitar lingkungan, seperti daun, pasir, tanah, dan tanaman. Tujuannya agar anak memiliki konsep sendiri dan dapat bersosialisasi terhadap lingkungan.

4. Sentra Seni dan Kreativitas

Sentra yang menyediakan fasilitas agar anak dapat berkreasi dan melatih sensori motornya. Dilihat dari cara anak mengekspresikan 
dirinya melalui aktivitas seni seperti bernyany i, kreasi, tarian, ataupun gerak lagu. Sentra ini bertujuan agar anak berfikir kreatif.

5. Sentra Main Peran

Sentra yang menyediakan fasilitas anak untuk meningkatkankan daya ingatnya, berimajinasi, berekspresi serta bereksplorasi. Pada sentra peran ditekankan cara anak bereksplorasi sebaik mungkin dengan dirinya. Tujuannya adalah agar anak dapat bersoalisasi dan berinteraksi. Menurut Piaget (1962):

"Dengan bermain drama, anak mengadaptasi realitas kehidupan dengan ketertarikan dan pengetahuannya sendiri. Sebagai salah satu bentuk paling murni dari pemikiran simbolis yang tersedia bagi anak, bermain drama memberi kontribusi sangat kuat pada perkembangan intelektual anak." (Yudhistira \& Siska Y. Massardi, 2012)

6. Sentra IMTAQ

Sentra ini fokus pada kegiatan agama. Seperti, menghafal doa dan surat-surat pendek, dan juga pengenalan Fiqih. Penekanan pada sentra ini adalah pembelajaran agama Islam. Adapun tujuan dari sentra ini yaitu membentuk akhlak mulia anak, dan membuat anak senang beribadah dengan cara yang baik.

Dalam sentra, terdapat langkah-langkah yang sedikit berbeda dari model pembelajaran lainnya. Langkah pertama yaitu persiapan pembelajaran dengan menyiapkan Rencana Kegiatan Harian (RKH), kemudian melaksanakan empat pijakan (Scaffolding) guna mendukung perkembangan anak. Rencana pembelajaran dan empat pijakan bermain sebagai berikut:

1. Persiapan Pembelajaran pembuatan dan penyusunan RKH (Rencana Kegiatan Harian). RKH adalah perangkat pembelajaran yang dijadikan sebagai pedoman suatu kegiatan 
dan mengacu pada rencana pelaksanaan mingguan sesuai dengan tema yang telah disepakati

2. Pijakan lingkungan main; guru dapat mempersiapkan pijakan lingkungan main dengan alat dan bahan dengan jumlah cukup, merencanakan intensitas permainan, menyediakan bahan pendukung

Latif dan Vygotsky mengemukakan pijakan lingkungan main yaitu:

"Mengelola awal lingkungan main dengan bahan-bahan yang cukup, merencanakan untuk itensitas dan densitas pengalaman, memiliki berbagai bahan yang mendukung tiga jenis main, memiliki bahan yang mendukung pengalaman keaksaraan, menata kesempatan main untuk mendukung hubungan sosial yang positif' (Fitriana, 2018)

3. Pijakan sebelum main; duduk melingkar, mengucap salam, bertanya kabar, dan kegiatan pembuka lainnya

4. Pijakan individu atau saat main; memberi anak waktu untuk bermain dan memperluas pengalamannya saat bermain, guru berkeliling antara anak-anak, mencontohkan komunikasi yang baik, membantu anak yang kesulitan, memotivasi anak untuk mencoba permainan lain, memberitahu waktu bermain jika akan selesai

5. Pijakan setelah bermain; mengingatkan kembali kepada anak tentang pengalaman mainnya dan menceritakan hal tersebut, anak juga diajak untuk merapihkan kembali mainan yang telah digunakan

6. Evaluasi Pembelajaran

Evaluasi pembelajaran dilakukan guna melihat sejauh mana keberhasilan pembelajaran yang telah dilaksanakan. Mulai dari perkembangan anak, media dan cara mengajar yang dilakukan 
atau untuk menilai guru itu sendiri. Evaluasi sangat penting dan merupakan bagian yang tidak terpisahkan dari pembelajaran, dengan evaluasi, pembelajaran bisa ditingkatkan, ataupun dikurangi untuk mencapai tujuan pembelajaran itu sendiri.

Untuk melaksanakan proses pembelajaran sentra yang efektif dan sesuai dengan prinsip pembelajaran sentra, perlu dilakukan beberapa persiapan bagi pihak sekolah dalam menyiapkan guru yang kompeten, fasilitas pembelajaran yang memadai, dan pengenalan kepada orangtua atau walimurid mengenai pembelajaran sentra. Hal itu sangat penting, supaya tujuan dari pembelajaran sentra dapat tercapai dengan maksimal sehingga menghasilkan anak-anak yang cerdas gemilang.

\section{Nilai-Nilai Karakter Dalam Pembelajaran Sentra}

Berikut disajikan secara singkat nilai-nilai karakter dalam berbagai jenis sentra (Ismail, 2013) melalui pijakan dan kegiatan dalam sentra:

\begin{tabular}{|c|c|c|c|c|c|c|}
\hline \multirow{2}{*}{$\begin{array}{c}\text { Nilai } \\
\text { Karakter }\end{array}$} & \multicolumn{6}{|c|}{ Jenis Sentra } \\
\hline & Persiapan & Imtaq & Balok & $\begin{array}{l}\text { Main } \\
\text { Peran }\end{array}$ & Seni & $\begin{array}{l}\text { Bahan } \\
\text { Alam }\end{array}$ \\
\hline Religius & $\checkmark$ & $\checkmark$ & $\checkmark$ & $\checkmark$ & $\checkmark$ & $\checkmark$ \\
\hline Nasionalis & $\checkmark$ & $\checkmark$ & $\checkmark$ & $\sqrt{ }$ & $\sqrt{ }$ & $\sqrt{ }$ \\
\hline Mandiri & $\checkmark$ & $\checkmark$ & $\checkmark$ & $\checkmark$ & $\checkmark$ & $\checkmark$ \\
\hline $\begin{array}{l}\text { Gotong } \\
\text { Royong }\end{array}$ & $\checkmark$ & $\checkmark$ & $\checkmark$ & $\checkmark$ & $\checkmark$ & $\checkmark$ \\
\hline Integritas & $\checkmark$ & $\checkmark$ & $\checkmark$ & $\checkmark$ & $\checkmark$ & $\checkmark$ \\
\hline
\end{tabular}

Tabel 1.1 
Dari tabel diatas, lima nilai karakter bisa dimunculkan pada setiap sentra melalui pijakan dan kegiatan main dalam sentra. Adapun nilai karakter yang sepatutnya diupayakan untuk dimunculkan pada setiap sentra ialah nilai karakter religius, yaitu menanamkan kecintaan anak kepada Tuhan Yang Maha Esa. Hal ini tentu saja wajib, dalam (Ismail, 2013) rasa cinta anak kepada Tuhan Yang Maha Esa diharapkan dapat menjadi langkah awal atau landasan sebelum kecintaan anak kepada manusia lainnya, sehingga secara spontan muncul karakter-karakter lain yang berhubungan dengan dirinya sendiri (misalnya integritas, mandiri) maupun yang berkaitan dengan sesama (nasionalis, gotong royong)

Nilai-nilai karakter diatas tersebut tidak berarti dapat muncul bersamaan dalam satu kesempatan kegiatan sentra, bisa saja pada saat itu terlihat karakter tersebut, namun di lain hari muncul karakter yang berbeda. Untuk mengoptimalkan nilai karakter tersebut, pembiasaan pada sentra harus selalu diterapkan secara konsisten. Selain itu, dibutuhkan teladan dari seorang guru. Islam berpandangan bahwa, pemberian teladan dianggap sebagai teknik pendidikan yang paling membekas bagi anak didik (Ismail, 2013). Misalnya; pada sentra Imtaq guru mengajak anak untuk berwudhu secara baik dan benar, pada sentra balok guru mengajak anak untuk bekerjasama membuat sebuah bangunan, pada sentra bahan alam guru bisa mengajak anak untuk mencintai alam ciptaan Allah, pada sentra seni guru bisa mengajak anak berkreasi menciptakan karya, dan pada sentra main peran guru bisa mengajak anak bermain peran menjadi pemadam kebakaran yang menolong sesama.

Dalam konteks ini, guru merupakan kunci dalam pelaksana proses pembelajaran sentra dalam satuan PAUD/TK/RA dan sejenisnya. Guru 
harus mampu menghayati nilai-nilai karakter yang diberikan kepada anak, sehingga mampu mengoptimalkan pendidikan karakter dalam sentra.

2. Pendidikan Karakter Anak Usia Dini Melalui Model Pembelajaran Sentra (Beyond Center and Circle Time)

Guru diharapkan sudah mempersiapkan sejak awal mengenai nilainilai karakter yang akan diterapkan dan dimunculkan pada anak, sarana dan prasarana, bahan dan alat yang dibutuhkan, model penilaian, serta komponen lain yang mendukung demi terlaksananya pendidikan karakter melalui model pembelajaran sentra. Hal ini yang disebut sebagai usaha penanaman karakter secara terencana, melalui sebuah manajemen yang berupa pengelolaan, mencakup perencanaan, pelaksanaan serta pengendalian kegiatan yang dilakukan.

Terdapat beberapa perangkat pembelajaran berupa perencanaan yang perlu di buat oleh guru sesuai dengan materi pembelajaran yang akan dilaksanakan. Adapun perangkat pembelajaran sentra salah satunya adalah Rencana Kegiatan Harian (RKH).

Berikut contoh Rencana Kegiatan Harian (RKH) berbasis sentra dengan lima nilai utama karakter Perpres No.87 Tahun 2017:

\section{RENCANA KEGIATAN HARIAN (RKH)}

Tema/Sub Tema: Lingkunganku/Rumahku

Sentra: Balok

Kelompok: A1 (4-5 Tahun)

Hari, Tanggal: Senin, 13 Januari 2020 


\section{Tujuan Pembelajaran:}

1. Anak bisa berdoa sebelum dan sesudah kegiatan

2. Anak bisa melakukan gerakan merangkak

3.Anak bisa mengetahui dua macam nama dan bentuk balok

4. Anak bisa menyanyikan lagu-lagu anak sederhana

5. Anak mengenal aturan bermain di sentra balok

\section{Konsep pengetahuan:}

1. Bentuk bangunan rumah

2. Lagu dan irama

3. Pelafalan kata

\section{Kegiatan pembelajaran}

1. Aktivitas awal sekolah (07.00-08.00)

Berbaris di halaman, ikrar, bernyanyi, doa

Pengembangan Karakter: Religius, Integritas, Mandiri

2. Pijakan Lingkungan (Setting tempat, alat dan bahan main)

Menata kelas sesuai tema, menyediakan alat dan bahan yang akan dipakai (masing-masing sentra)

a) Tempat main: guru mempersiapkan balok-balok yang akan digunakan bermain hari ini

b) Ragam main: menggunakan dua macam balok, segitiga dan persegi panjang, serta memakai hiasan-hiasan seperti pohon, boneka manusia, dan mobil-mobilan

Pengembangan karakter: Integritas

3. Pijakan Sebelum Main (30 menit)

a. Anak diajak melakukan aktivitas motorik kasar dengan melakukan ice breaking dan iringan lagu. Kemudian guru mengucap salam, dan anak menjawab salam 
b. Guru dan anak duduk membentuk lingkaran, berdoa, absen, dan mengenalkan permainan yang akan dilakukan serta aturan-aturan bermain di sentra balok

Pengembangan karakter: Religius, Nasionalis

4. Pijakan saat bermain (60 menit)

a) Guru mempersilahkan anak-anak untuk bermain dan bereksplorasi mengenai bentuk bangunan rumah dari balok

b) Guru memotivasi anak-anak untuk semangat melakukan kegiatan

c) Guru membantu anak yang kesulitan

d) Guru mencatat penilaian anak selama kegiatan berlangsung

e) Guru mengingatkan jika waktu akan habis

Pengembangan Karakter: Nasionalis (taat pada aturan bermain), gotong royong (bekerjasama dengan kelompoknya membentuk bangunan rumah), mandiri (mengambil balok sendiri di tempat yang disediakan

5. Pijakan setelah bermain (15 menit)

a) Anak-anak merapihkan kembali balok yang digunakan ke tempat semula

b) Guru bertanya kembali kegiatan main yang telah dilakukan tadi (Recalling)

Pengembangan Karakter: Mandiri, Gotong Royong,

1. Istirahat dan Snacktime (30 menit)

a) Cuci tangan, dan berdoa sebelum makan

b) Makan, bermain bebas bersama

Pengembangan Karakter: Nasionalis (taat pada aturan sebelum makan dan sesudah makan, seperti cuci tangan, duduk dan tidak 


berbicara ketika makan), mandiri (mengambil dan makan
makanannya sendiri), serta gotong royong (main bersama), religius
(berdoa sebelum dan sesudah makan)
2. Penutup
a) Guru memberikan pesan kebaikan kepada anak
b) Bernyanyi lalu berdoa sebelum pulang
Pengembangan Karakter: Religius, dan mandiri

Tabel 1.2

Sumber: (Ismail, 2013)

Penjelasan dari Rencana Kegiatan Harian (RKH) diatas ialah:

a. Aktivitas awal di Sekolah

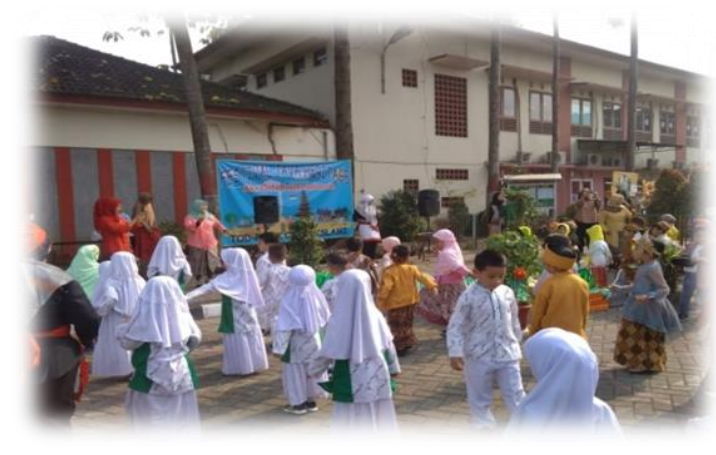

Gambar 1.1

Kegiatan baris di halaman

Pendidikan karakter dimulai dari kegiatan awal sekolah ketika anak belum masuk ke dalam kelas, dengan kegiatan berbaris terlebih dahulu untuk melakukan kegiatan berdoa bersama. Dalam kegiatan ini, karakter yang dimunculkan ialah nilai karakter religius, yaitu ketika anak mengetahui sikap dan dapat melafadzkan doa yang 
dipanjatkan. Guru juga dapat memunculkan karakter Integritas ketika bertanya kepada anak-anak siapa yang bersedia menjadi pemimpin doa. Dengan begitu, anak akan merasa dipercaya dan bertanggungjawab untuk memimpin doa dari awal hingga selesai. Dalam nilai karakter mandiri ditunjukkan ketika anak melepas dan menyimpan sepatunya sendiri di rak sepatu dan memasuki sentra masing-masing.

b. Pijakan Lingkungan Main

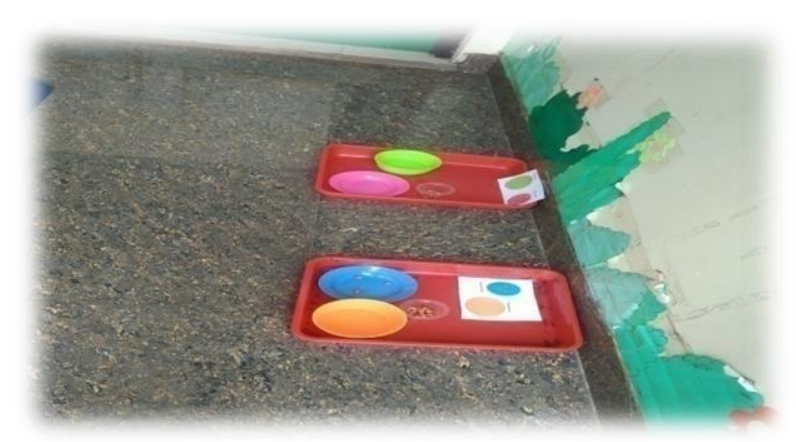

Gambar 1.2

Alat dan bahan main

Mencerminkan perencanaan pembelajaran yang telah dibuat, guru menyiapkan alat dan bahan sesuai tempatnya masing-masing. Dalam nilai karakter yang dimunculkan di kegiatan ini adalah nilai karakter gotong royong, peduli dengan lingkungan sosialnya.

c. Pijakan Sebelum Main 


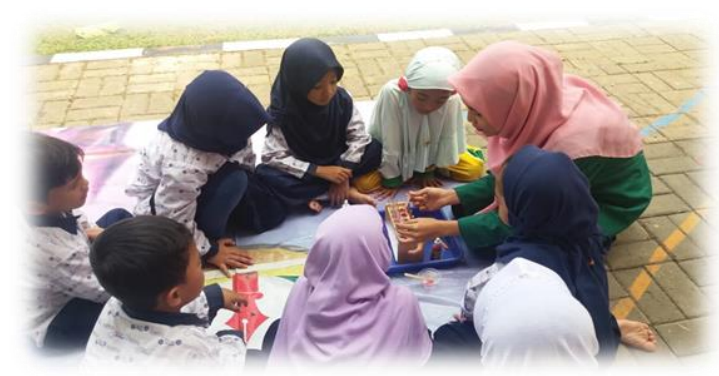

Gambar 1.3

Kegiatan Circle Time

Pijakan sebelum main ialah kegiatan duduk melingkar (circle time), bernyanyi, berdoa dan absen. Guru bertanya kepada anak siapa yang tidak hadir hari ini, anak-anak akan menjawab nama temannya yang tidak hadir, karakter yang muncul dalam kegiatan ini adalah integritas yaitu ketika anak peduli dengan lingkungan sosialnya. Karakter religius, ketika anak-anak mengucap dan menjawab salam pada saat kegiatan berlangsung, serta ketika anak-anak khusyu dalam do’a. Sebelum main, guru juga memberikan aturan-aturan main, dan mempraktikkan cara bermainnya. Di kegiatan ini karakter yang dimunculkan ialah nilai karakter nasionalis, cinta tanah air dengan menaati aturan-aturan main yang telah dijelaskan guru.

a. Pijakan Saat Bermain

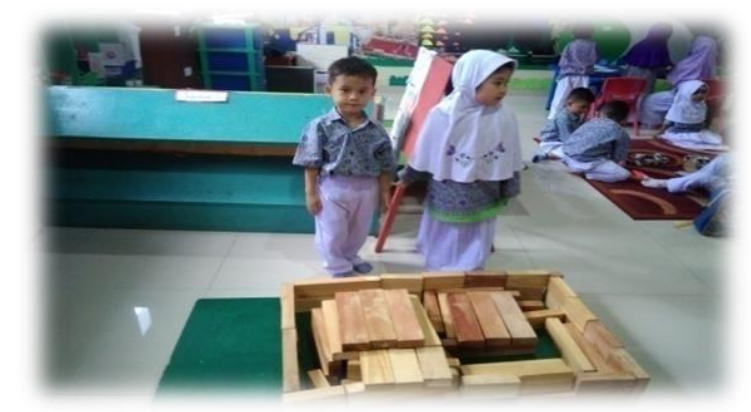

Gambar 1.4

Kegiatan Bermain Balok 
Saat kegiatan main berlangsung, banyak karakter yang akan dimunculkan anak sesuai dengan nilai-nilai karakter yang akan diberikan dan sudah terencana dalam Rencana Kegiatan Harian $(\mathrm{RKH})$ dan kegiatan sentra yang diberikan.

b. Pijakan Setelah Bermain

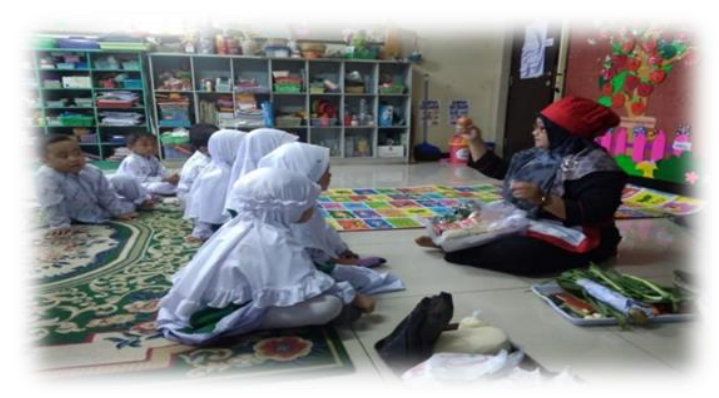

Gambar 1.5

Kegiatan setelah bermain

Setelah kegiatan bermain selesai, karakter yang dimunculkan adalah nilai karakter gotong royong ketika anak-anak bersama-sama merapihkan kembali alat main yang yang digunakan. Karakter mandiri, yaitu mengembalikan mainan ke tempat semula.

Pendidikan karakter melalui model pembelajaran sentra tentu sangat memerlukan dukungan evaluasi pembelajaran. Hal ini penting terutama untuk mengetahui sejauh mana keberhasilan mengenai perkembangan anak setelah diberikan pendidikan karakter melalui model pembelajaran sentra. Evaluasi bisa dilakukan dalam waktu harian, mingguan, atau bulanan, serta dilakukan seiring berlangsungnya proses pembelajaran. Jadi, guru bisa melakukan dokumentasi, mencatat kegiatan-kegiatan yang berkenaan dengan nilai-nilai karakter tersebut pada setiap pijakan, itu dilakukan bila memungkinkan. Meskipun evaluasi bersifat penting, namun tidak perlu menganggu proses 
pembelajaran, karena itu akan mempengaruhi konsentrasi guru dalam melihat dan menilai perkembangan anak ketika sedang bermain.

\section{SIMPULAN}

Dalam Perpres No.87 Tahun 2017, disebutkan bahwa seorang anak harus berkarakter religius, agar tumbuh menjadi seseorang yang taat pada agama, sebagai konsep ketauhidan, dan memperluas khazanah keagamaan. Nasionalis, dapat bertoleransi dan menghargai perbedaan, memiliki semangat juang yang tinggi untuk mengharumkan nama bangsa. Mandiri, agar anak bisa melakukan sesuatu sendiri, tidak bergantung kepada orang lain, karakter tersebut mendorong anak agar mampu menjadi pembelajar sepanjang masa. Gotong royong, karakter yang menjadikan anak senang bersosialisasi, memiliki empati dan solidaritas yang tinggi terhadap teman maupun sesama, cinta kebersamaan. Terakhir, integritas, akan membuat seorang anak tumbuh menjadi dewasa yang percaya diri, dan dapat diandalkan.

Ada berbagai macam sentra, yaitu sentra persiapan ialah tempat yang menjadi bekal keaksaraan anak, salah satunya ialah mencintai literasi. Sentra seni ialah wahana anak untuk berkreasi dan memacu kreatifitasnya dengan berbagai macam karya. Sentra balok, sebagai wadah untuk menggali ilmu pengetahuan seluas-luasnya, khususnya mengenai dunia bangunan. Sentra Imtaq, mengenalkan anak tentang konsep keagamaan secara sederhana. Sentra bahan alam, mengenalkan anak berbagai macam benda dan keajaiban alam semesta. Sentra main peran, ialah menggambarkan secara objektif kepada anak tentang berbagai peran di dunia beserta dinamika kehidupan.

Pendidikan karakter yang diimplementasikan melalui model pembelajaran sentra terdiri dari beberapa proses seperti perencanaan, pelaksanaan dan evaluasi. Nilai-nilai karakter bisa dimunculkan pada setiap kegiatan sentra sesuai dengan perencanaan yang telah dirancang. Hal tersebut 
penting untuk diterapkan karena karakter positif anak akan muncul melalui pembiasaan yang dilakukan secara konsisten dan berkelanjutan dalam kegiatan sentra. Sehingga apabila penerapan nilai-nilai karakter tersebut sudah berjalan dengan tepat dan lancar setiap harinya, baik di sekolah, maupun dirumah, maka akan menghasilkan anak-anak yang berkarakter, cerdas dan gemilang.

\section{REFERENSI}

Anshori, I. (2017). Penguatan Pendidikan Karakter di Madrasah. Islamic Education Journal, 65.

Ar-Raisul Karama Arifin \& Nur Ainy Fardana. (2014). Peran Pendidikan PAUD Dalam Mengimplementasikan Pendidikan Karakter Melalui Metode Pembelajaran Sentra dan Lingkaran. Jurnal Psikologi Pendidikan dan Perkembangan, 192.

Atik Maisaro, Bambang Budi Wiyono \& Imron Arifin. (2018). Manajemen Program Penguatan Pendidikan Karakter di Sekolah Dasar. Jurnal Administrasi dan Manajemen Pendidikan, 305.

Fitriana, E. (2018). Model Pembelajaran Sentra Di TK ISLAM TERPADU QURROTA A'YUN BANDAR LAMPUNG. SKRIPSI, 29.

Ismail. (2013). Integrasi Pendidikan Karakter Anak Usia Dini Melalui Model Pembelajaran Berbasis Beyond Centers And Circle Time (BCCT). Jurnal Pendidikan Anak, 43. 
Marbun, S. M. (2018: 10). Psikologi Pendidikan. Ponorogo: Uwais Inspirasi Indonesia.

Maunah, B. (2015). Implementasi Pendidikan Karakter Dalam Pembentukan Kepribadian Holistik Siswa. Jurnal Pendidikan Karakter, 91.

Rianawati. (2014). Implementasi Nilai-Nilai Karakter Pada Mata Pelajaran.

Veny Iswantiningtyas \& Widi Wulansari. (2019). Penanaman Pendidikan Karakter Pada Model Pembelajaran BCCT (Beyond Centers and Circle Time. Jurnal Pendidikan Anak Usia Dini, 111.

Wiyani, N. A. (2017). Perencanaan Strategik Pembentukan Karakter Anak Usia Dini di TK Islam al-Irsyad Purwokerto. Al-Athfal: Jurnal Pendidikan Anak, 110. 